\title{
From Select Agent to an Established Pathogen: The Response to Phakopsora pachyrhizi (Soybean Rust) in North America
}

\author{
Heather Y. Kelly, Nicholas S. Dufault, David R. Walker, Scott A. Isard, Raymond W. Schneider, Loren J. Giesler, \\ David L. Wright, James J. Marois, and Glen L. Hartman
}

First author: Department of Entomology and Plant Pathology, West Tennessee Research and Education Center, University of Tennessee, Jackson 38301; second author: Department of Plant Pathology, University of Florida, Gainesville 32611; third and ninth authors: United States Department of Agriculture-Agricultural Research Service and Department of Crop Sciences, University of Illinois, Urbana 61801; fourth author: Departments of Plant Pathology and Meteorology, Pennsylvania State University, University Park 16802; fifth author: Department of Plant Pathology and Crop Physiology, Louisiana State University Agricultural Center, Baton Rouge 70803; sixth author: Department of Plant Pathology, University of Nebraska-Lincoln, Lincoln 68182; seventh author: Department of Agronomy, North Florida Research and Education Center (NFREC), University of Florida, Quincy 32351; and eighth author: Department of Plant Pathology, NFREC, University of Florida, Quincy 32351 and Gainesville 32611.

Accepted for publication 9 March 2015.

\begin{abstract}
Kelly, H. Y., Dufault, N. S., Walker, D. R., Isard, S. A., Schneider, R. W., Giesler, L. J., Wright, D. L., Marois, J. J., and Hartman, G. L. 2015. From select agent to an established pathogen: The response to Phakopsora pachyrhizi (soybean rust) in North America. Phytopathology 105:905-916.

The pathogen causing soybean rust, Phakopsora pachyrhizi, was first described in Japan in 1902. The disease was important in the Eastern Hemisphere for many decades before the fungus was reported in Hawaii in 1994, which was followed by reports from countries in Africa and South America. In 2004, P. pachyrhizi was confirmed in Louisiana, making it the first report in the continental United States. Based on yield losses from

countries in Asia, Africa, and South America, it was clear that this pathogen could have a major economic impact on the yield of 30 million ha of soybean in the United States. The response by agencies within the United States Department of Agriculture, industry, soybean check-off boards, and universities was immediate and complex. The impacts of some of these activities are detailed in this review. The net result has been that the once dreaded disease, which caused substantial losses in other parts of the world, is now better understood and effectively managed in the United States. The disease continues to be monitored yearly for changes in spatial and temporal distribution so that soybean growers can continue to benefit by knowing where soybean rust is occurring during the growing season.
\end{abstract}

The pathogen causing soybean rust, Phakopsora pachyrhizi Syd., was first described in Japan in 1902 (Hennings 1903). Over the next 90 years, the fungus was reported on soybean and related species throughout the Eastern Hemisphere, including Australia, China, India, Indonesia, Japan, Taiwan, and other countries in tropical and subtropical regions (Bromfield 1984). By 1994, P. pachyrhizi had spread beyond the Eastern Hemisphere and into Hawaii (Killgore et al. 1994) and, just a few years later, it was reported in many countries in Africa and South America. In Africa, P. pachyrhizi was reported in Kenya, Rwanda, and Uganda in 1996, followed by Zambia and Zimbabwe in 1998, Nigeria in 1999, Mozambique in 2000, South Africa in 2001, Ghana and the Democratic Republic of Congo in 2007, and Malawi and Tanzania in 2014 (Murithi et al. 2015). In South America, the first reports of $P$. pachyrhizi were in Paraguay, followed by Brazil, in 2001 (Yorinori et al. 2005). In 2004, soybean leaf samples from a location north of the equator in Columbia tested positive for P. pachyrhizi (Isard et al. 2005) and, on 6 November 2004, the disease was discovered in Louisiana (Schneider et al. 2005). Over the subsequent decade, $P$. pachyrhizi was recorded in soybean and jicama production regions in Mexico, and seasonally on soybean and kudzu in 17 U.S. states, and at a single location on soybean in Ontario, Canada (http://sbr.ipmpipe.org).

The early movement of $P$. pachyrhizi in the Eastern Hemisphere is not well documented. A recent study using quantitative

Corresponding author: G. L. Hartman; E-mail address: glen.hartman@ ars.usda.gov

http://dx.doi.org/10.1094/PHYTO-02-15-0054-FI

This article is in the public domain and not copyrightable. It may be freely reprinted with customary crediting of the source. The American Phytopathological Society, 2015. polymerase chain reaction (PCR) primers specific to $P$. pachyrhizi identified 11 occurrences of $P$. pachyrhizi in rust herbarium specimens, including a 1912 soybean leaf from Japan, a 1913 leaf of Pachyrhizus sp. from Taiwan, and a 1924 leaf of Pueraria sp. from the Philippines; P. pachyrhizi was not found outside of Asia or Australia before 1994, indicating that $P$. pachyrhizi may have been endemic to the Eastern Hemisphere (Haudenshield and Hartman 2015) despite an early report of its occurrence in Africa in the 1970s (Javid and Ashraf 1978). The potential threat of soybean rust to soybean in the United States was nevertheless recognized, and research on the pathogen began at what is now called the United States Department of Agriculture-Agricultural Research Service (USDA-ARS) Foreign Disease-Weed Science Research Unit (FDWSRU) Biosafety Level 3 (BSL-3) plant pathogen containment facility at Fort Detrick, MD in 1972 (Bonde and Peterson 1995).

The emergence of $P$. pachyrhizi as a major soybean pathogen in countries in Africa and South America prompted additional concerns and allocation of resources in the United States to address soybean rust. On 16 January 2004, the USDA published a detailed and prescient document entitled "National Strategic Plan for the Integration and Coordination of Soybean Rust Research" (USDA 2004). Preceding this plan, there were several research projects headed by U.S. scientists working outside the country that were launched to assess fungicide efficacy, soybean rust resistance, aspects of fungal biology, and disease epidemiology (Isard et al. 2006a; Miles et al. 2003a,b, 2006, 2007). This early work, along with information and warnings from international colleagues about P. pachyrhizi, especially from Brazil and Paraguay, and interactions with scientists at the USDA-ARS facility in Fort Detrick, where researchers had worked on the fungus for the past several decades 
(Bonde and Peterson 1995), provided the knowledge base in the United States to have grower meetings and educational workshops to teach others more about soybean rust and $P$. pachyrhizi. A workshop was organized at Fort Detrick in April 2004 in which participants could view soybean rust firsthand in their secure greenhouses, and this experience was instrumental in being able to recognize the disease in a production field in Louisiana in November of that year. These experiences provided pathologists in the United States with the tools needed to address soybean rust and to monitor its progress.

\section{CLASSIFICATION, INFECTION, HOST RANGE, AND VIRULENCE}

Classification. P. pachyrhizi (synonym: Malupa sojae) is in an obligate parasite that belongs to the order Uredinales, which includes many rust fungi that may have up to five spore types; however, $P$. pachyrhizi has exhibited only three spore types: urediniospores, teliospores, and basidiospores. Of these, only the urediniospores have been considered important for disease development because infection by basidiospores has not been observed, even though telia have been reported in the United States (Harmon et al. 2006). A closely related species, P. meibomiae (Arthur) Arthur (Ono et al. 1992), thought to be endemic to the Western Hemisphere, also causes rust on legumes but is much less aggressive on soybean than $P$. pachyrhizi and is not considered a threat to production. Prior to the recognition that these were two distinct species, both were referred to as $P$. pachyrhizi and almost all of the literature before 1992 referred to soybean rust in Asia as being caused by P. pachyrhizi; P. meibomiae, often referred to as the "New World Rust", has not been reported on soybean in the Eastern Hemisphere or in the continental United States.

Infection process. Infection of host tissue by $P$. pachyrhizi in soybean is initiated when a urediniospore germinates to form a single germ tube that results in an appressorium, approximately the same size as a urediniospore (Hoppe and Koch 1989; Koch et al. 1983). An appressorial cone initiates the penetration into the epidermal cell by turgor pressure independent of melanin accumulation (Chang et al. 2014). Penetration hyphae grow through the epidermal cell and intercellular space, first forming primary invading hyphae, then secondary hyphae populating intercellular spaces (Bonde et al. 1976; Edwards and Bonde 2011; Koch et al. 1983; Vittal et al. 2014). In compatible interactions, primary haustoria form in the mesophyll cells, secondary haustoria form within 12 days, and a domed-shaped eruption occurs in the epidermis to form uredinia that often have a rusty appearance on infected leaves of both kudzu and soybean (Fig. 1). In an

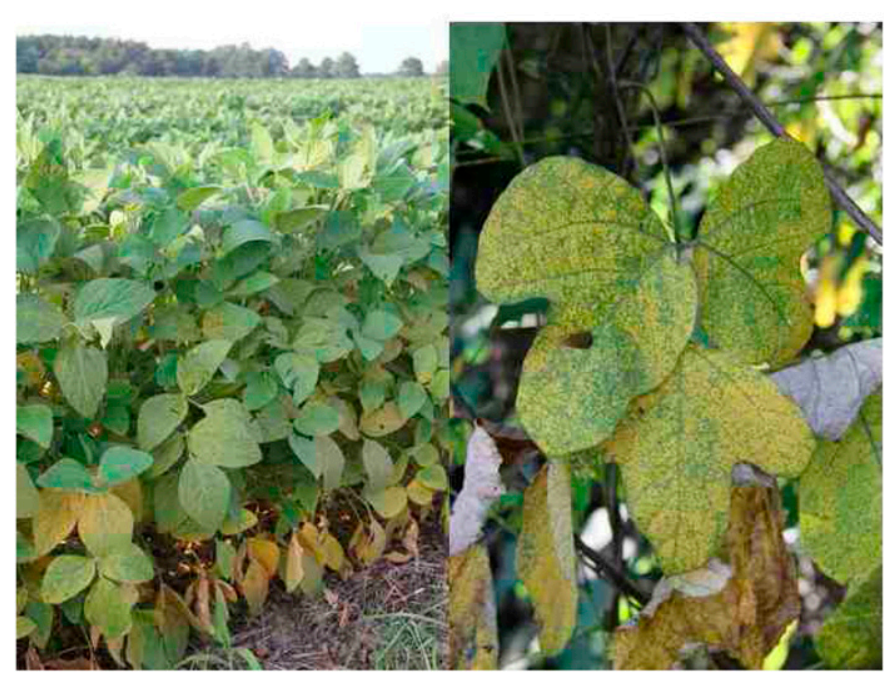

Fig. 1. Soybean and kudzu leaves infected by Phakopsora pachyrhizi (right and left) (Courtesy E. J. Sikora; from Hartman et al. 2015). incompatible interaction, branching of fungal hyphae in the mesophyll is not common, and is associated with mesophyll cell necrosis (McLean 1979). During the $24 \mathrm{~h}$ after inoculation, spore germination, appressorium formation, and fungal penetration of the epidermis in susceptible and resistant soybean genotypes are similar but, within 2 days, more hyphae occur in the mesophyll tissue of susceptible than in resistant genotypes, and mesophyll cell death is greater in soybean genotype with an immune response, demonstrating that an incompatible soybean-P. pachyrhizi interaction restricts hyphal development in the mesophyll cell tissue (Vittal et al. 2014). A very similar response was observed in kudzu as well, where the resistant interactions had early onset of a multicell hypersensitive response, while immune interactions were the result of a cell wall deposition that blocked penetration in combination with early onset of a hypersensitive response (Jordan et al. 2010) (Fig. 2).

Optimal conditions for spore germination are between 12 and $25^{\circ} \mathrm{C}$, with free moisture (e.g., dew) present for 10 to $12 \mathrm{~h}$ (Melching et al. 1989). Temperatures below $9^{\circ} \mathrm{C}$ and above $28^{\circ} \mathrm{C}$ inhibit spore germination (Bromfield 1984; Melching et al. 1989). Uredinia can produce spores for as long as 3 weeks, and a single lesion can maintain sporulating uredinia for up to 15 weeks (Koch et al. 1983; Marchetti et al. 1975). Urediniospores remain viable at room temperature ( 23 to $24^{\circ} \mathrm{C}$ at 55 to $60 \%$ relative humidity) for up to 18 days, and for up to 30 days when desiccated for $12 \mathrm{~h}$ prior to storage at room temperature (Twizeyimana and Hartman 2010). Under field conditions, urediniospore viability can be adversely affected by exposure to solar and ultraviolet radiation (Isard et al. 2006a).

Host range. Prior to the introduction of $P$. pachyrhizi to North America in 2004, there were 93 plant species in 42 genera listed as hosts of P. pachyrhizi (Ono et al. 1992). Hosts of P. pachyrhizi are restricted to species in the family Fabaceae and, more specifically, to the subfamily Papilionoideae, a monophyletic clade within Fabaceae (Wojciechowski et al. 2004). Current reported hosts from field studies in the United States were summarized by Hartman et al. (2011) and include coral bean, Florida beggarweed, green bean, kudzu, lima bean, scarlett runner bean, and soybean. In greenhouse evaluations, 65 species were identified as hosts, of which 62 occur in Alabama, Florida, Louisiana, Mississippi, and Texas (Slaminko et al. 2008). The large host range of $P$. pachyrhizi reflects the diversity and complexity of the virulence of this pathogen and may contribute to its survival and overwintering on "green bridges" such as kudzu in the southern United States. Currently, P. pachyrhizi is known to infect 158 species in 54 genera and is likely to expand as more potential hosts are examined.

Virulence of $\boldsymbol{P}$. pachyrhizi. Isolates of $P$. pachyrhizi interact with different soybean genotypes to produce three infection types (Bromfield 1984; McLean and Byth 1980): (i) type 0, an "immune" or near-immune infection type without visible lesions; (ii) RB, characterized by reddish-brown lesions with 0 to 2 uredinia per lesion and meager sporulation, indicative of resistance; and (iii) TAN, having tan lesions with two or more uredinia and abundant sporulation indicative of susceptibility. Variations in both the RB and TAN reaction types occur with increasing incremental levels of sporulation (Bromfield 1984). In addition to the primary infection types, reaction types with varying lesion colors, including black lesions, have been reported (Bonde et al. 2006; Slaminko et al. 2008). The variability in reaction types is the result of differential interaction between the host genotype, soybean rust pathotype, and environmental conditions. These primary reaction types also were reported on kudzu, with $\mathrm{RB}$ reactions having reduced sporulation or a significantly lower proportion of sporulating uredinia, fewer uredinia per lesion or area, lower lesion density, and longer latent periods than TAN reactions on susceptible plants (Bonde et al. 2009, Jordan et al. 2010; Young et al. 2011a) (Table 1).

In 1966, different reaction types were observed on five legume species, including soybean, in response to inoculation with nine isolates of $P$. pachyrhizi (Lin 1966). Since 1972, the USDA-ARS 
FDWSRU at Fort Detrick has housed and conducted research on a geographically diverse collection of isolates of $P$. pachyrhizi (Bonde and Peterson 1995). In addition to this early work, others have maintained and characterized isolates for virulence testing (Table 2). These collections have been used to document diversity in virulence and aggressiveness among isolates, to better understand conditions promoting host receptivity and pathogen infectivity, and for defining the genetics of host plant resistance. All of these studies have shown host genotype- and pathotype-specific interactions, indicating strong host specialization in P. pachyrhizi (Table 2).

\section{EPIDEMIOLOGY}

Kudzu and overwintering. The obligate biotrophic nature of $P$. pachyrhizi means that the pathogen requires alternative hosts to survive winters in the continental United States. Although P. pachyrhizi has a large host range, kudzu may be the only overwintering host that can provide large amounts of living tissue for winter survival along the Gulf Coast or farther south (Jurick et al. 2008; Pivonia and Yang 2004; Sikora 2014). From these sites, urediniospores produced in the spring spread to other kudzu patches and soybean fields. A study on epidemics across landscapes indicated that epidemics of airborne pathogens in landscapes with both wild and domesticated hosts are chiefly driven by the most abundant host species (Fabiszewski et al. 2010). In addition to being an important initial source for urediniospores, kudzu could also be a source of selection pressure for the pathogen population. For example, inoculum prepared from infected kudzu leaves collected in northcentral Florida in 2012 caused unusually high levels of soybean rust on a number of historically resistant soybean germplasm accessions (Walker et al. 2014a).
Interaction of $P$. pachyrhizi and kudzu genotypes. Approximately half of 125 kudzu plants grown from seed collected from 56 geographically distinct locations in Kentucky, Louisiana, Mississippi, and North Carolina and inoculated with three isolates of $P$. pachyrhizi produced an RB lesion type (Bonde et al. 2009). Additional studies showed that a considerable proportion of the kudzu in Florida is either immune (18\%) or resistant (32\%) (Jordan et al. 2010; Young et al. 2011b). Furthermore, in the majority of instances where multiple plants from a site were tested, each plant reacted similarly to three isolates of $P$. pachyrhizi (Bonde et al. 2009). Only $15 \%$ of individual plants produced a different reaction across three isolates, and all of the kudzu plants tested that previously produced an $\mathrm{RB}$ reaction to the three isolates also produced $\mathrm{RB}$ reactions to eight international isolates (Bonde et al. 2009), suggesting that susceptibility or resistance to $P$. pachyrhizi in individual kudzu sites is often broad, extending over multiple populations and isolates of $P$. pachyrhizi. These studies are important because they provide the basis for estimating urediniospore production in the beginning of a growing season and over the course of the season, in addition to the predominant virulence types for that season.

Potential amounts of urediniospores escaping from soybean and kudzu hosts. Estimates of soybean and susceptible and resistant kudzu areas in Florida and their respective epidemiological parameters as hosts of $P$. pachyrhizi were used to estimate the potential maximum number of urediniospores escaping from soybean and kudzu plants (Jordan et al. 2010; Young et al. 2011a). These estimates included those from the soybean rust spore escape rate model (Andrade et al. 2009) and a general soybean rust development model (Pivonia and Yang 2006) based on a mathematical model of epidemics in homogeneous and heterogeneous host stands (Gumpert 1989). In Florida, the amount of spores

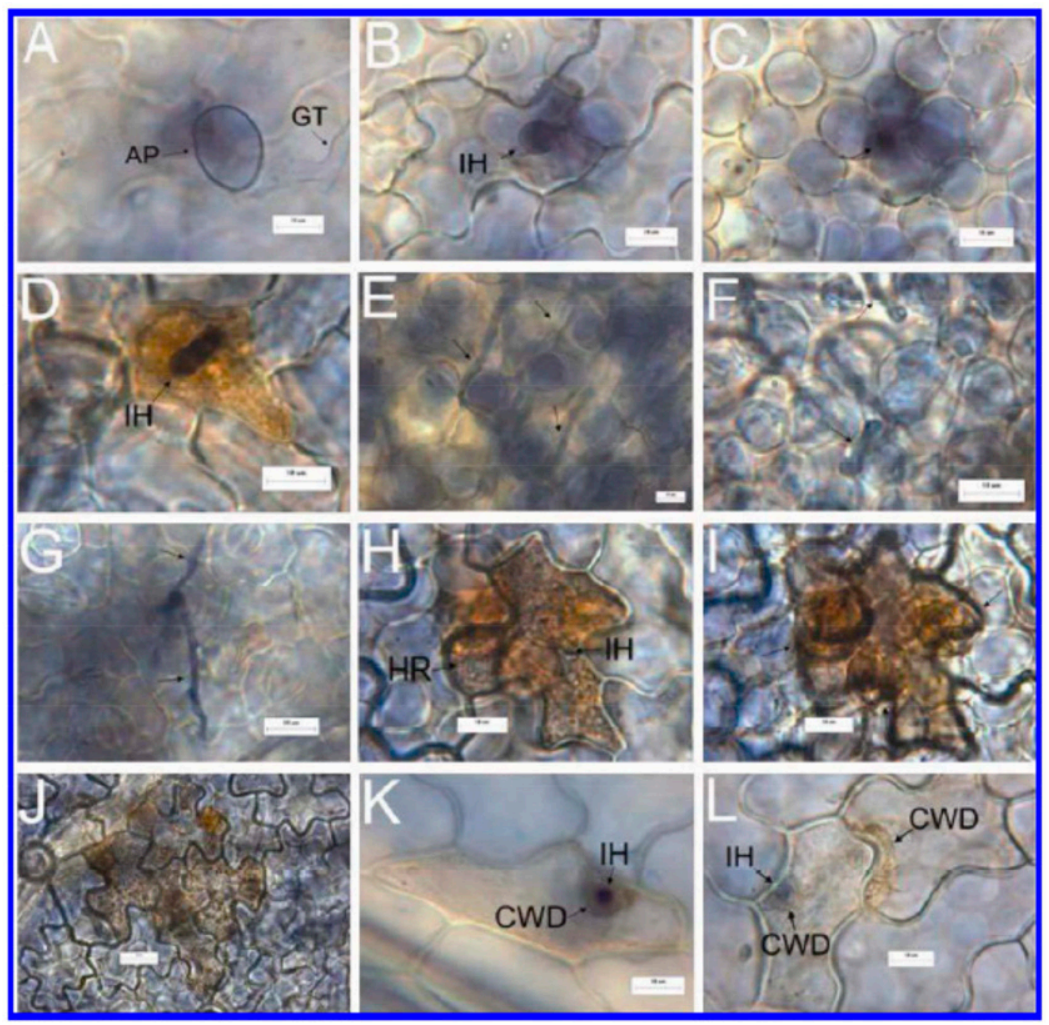

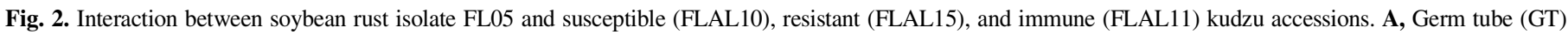

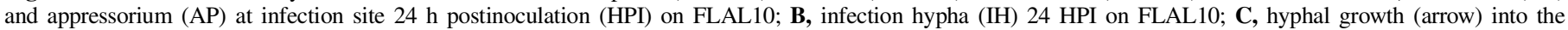

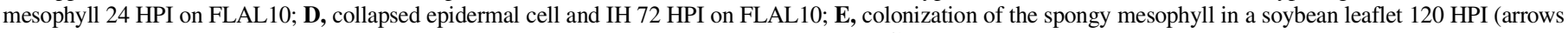

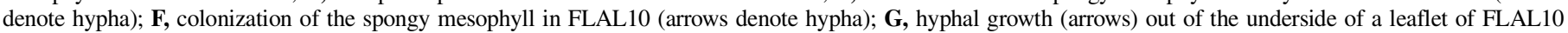

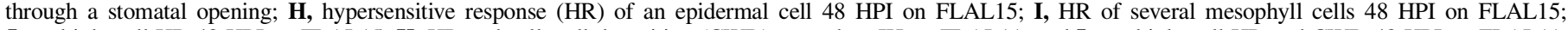

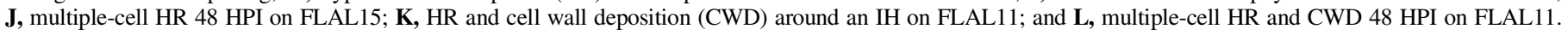


escaping from soybean (based upon 50\% leaf area affected), susceptible kudzu, and resistant kudzu was estimated at $6.7 \times 10^{12}$, $4.4 \times 10^{12}$, and $7 \times 10^{11}$ spores/day, respectively. Using the average initial infection date in Florida and optimum parameters from detached-leaf assays, the maximum amount of inoculum occurred 93 and 196 days after the initial infection on soybean (mid-September) and kudzu (late September), respectively. These estimates were based on the assumption that initial inoculum from overwintering hosts was low. The time required to reach maximum inoculum production may be quite different when young soybean crops are continually inundated with intense showers of urediniospores. These results indicate that, under optimal conditions and given the available area of hosts in Florida and the average time of disease onset, soybean and susceptible kudzu have the potential to supply inoculum from kudzu and soybean across landscapes, whereas resistant kudzu has low to no potential to generate inoculum for distribution to other areas.

Infection efficiency, latent period, and the spread of rust. Rust development based on detached-leaf assays from kudzu and soybean were used in a general disease model, which incorporated temperature effects on infection efficiency and latent period, to show that conditions for rust infection in Florida would occur in April for soybean ( 2 months prior to its usual appearance) and May for kudzu (Young et al. 2011a). This may explain why soybean rust epidemics on kudzu have been observed to develop slowly during the spring and early summer, despite detection early in the season, and the disease typically does not enter its exponential phase until late August, a month after soybean rust was reported in six southern states in 2005 and 2006 (Christiano and Scherm 2007). Considering only the epidemic on soybean, the disease expanded at an average rate of 8.8 and $10.4 \mathrm{~km} \mathrm{day}^{-1}$ in 2005 and 2006, respectively, resulting in limited regional spread of soybean rust (Christiano and Scherm 2007). This limited spread may be the result of slow disease progress on kudzu (Christiano and Scherm 2007; Jordan et al. 2010; Young et al. 2011a) combined with the short window for disease establishment on soybean that occurs primarily during its reproductive growth stages (Christiano and Scherm, 2007; Dorrance et al. 2008;
Sconyers et al. 2006); or it may be a result of low inoculum availability in 2005 and unusually dry conditions in 2006 (Christiano and Scherm, 2007). The situation may have been very different in 2005, which was a very active tropical storm and hurricane year (https://www.tropicalweather.net). Tropical storm Arlene and Hurricanes Dennis, Katrina, and Cindy moved across the Gulf Coast and into major soybean production areas from mid-June through the end of August. However, inoculum was very low because this was the first year after its initial discovery. Also, in 2012, Hurricane Isaac tracked from Louisiana into the Midwest at the end of August but source inoculum was very low that year in the mid-Gulf region, probably because of the unusually cold, subfreezing winters during the preceding 2 years (http://sbr.ipmpipe.org/cgi-bin/sbr/public.cgi).

Although kudzu provides the initial inoculum for epidemics on soybean, the rapid increase in disease prevalence on kudzu toward the end of the season may be driven, in part, by inoculum produced on soybean (Christiano and Scherm 2007; Young et al. 2011b). In addition, analyses of soybean rust epidemics from 2005 to 2011 showed a strong association between initial and final epidemic spread (Mundt et al. 2015); and the epidemics from 2005 to 2008 correlated a location's infection history (i.e., the previous number of years infected with soybean) to the previous year's incidence of soybean rust (Young et al. 2011b).

Long-distance dispersal of urediniospores. The physical characteristics (shape, size, density, and surface features) of urediniospores, such as those of $P$. pachyrhizi, are such that the energy in a turbulent atmosphere is often able to lift large numbers of spores from a plant canopy and keep them airborne for long periods of time (Gregory 1973). This energy also is used for spore liberation (mechanical vibration of plant parts), with the result that most urediniospores are released when the atmosphere is turbulent and, thus, conducive to spore transport (Gregory 1973). Rust urediniospores are able to remain viable for many days when exposed to the range of temperature and humidity conditions typically found in the lower atmosphere during the growing season (Aylor 1986). Dark pigmented

TABLE 1. Characterization of Phakopsora pachyrhizi infection when inoculated on soybean and kudzu genotypes from three different studies

\begin{tabular}{|c|c|c|c|}
\hline Variables & Susceptible soybean & Susceptible kudzu & Resistant kudzu \\
\hline \multicolumn{4}{|l|}{ Young et al. $2011 \mathrm{a}^{\mathrm{a}}$} \\
\hline Infection efficiency & 0.19 & 0.09 & 0.009 \\
\hline Urediniospores per uredinium & 45 & 36 & 13 \\
\hline \multicolumn{4}{|l|}{ Jordan et al. $2010^{\mathrm{b}}$} \\
\hline Lesions (per $\mathrm{cm}^{2}$ ) & 84 & 81 & 38 \\
\hline Uredinia per lesion per day & 3.2 & 2.1 & 1.5 \\
\hline Urediniospores per uredinium & 145 & 139 & 55 \\
\hline Uredinia per lesion & 4.7 & 3.2 & 0.3 \\
\hline Uredinia diameter $(\mu \mathrm{m})$ & 129 & 121 & 77 \\
\hline Proportion of lesions with sporulating uredinia & $\ldots$ & 4.9 & 1.0 \\
\hline
\end{tabular}

a Isolates of P. pachyrhizi were collected from infected kudzu in Quincy, FL in 2010. These isolates were used to inoculate one susceptible (tan lesions) soybean genotype (Pioneer 95Y20RR), two susceptible kudzu genotypes, and two resistant (red-brown lesions with restricted urediniospore production) kudzu genotypes. After inoculation of detached leaflets, the following variables were evaluated. The infection efficiency was the average number of uredinia produced 20 days postinoculation on each genotype divided by the number of viable spores, which was determined by the amount of spores applied to inoculation area and average germination rate. Urediniospores per uredinia per day were calculated by dividing the spore production per $50 \mathrm{~mm}^{2}$ per day by the number of uredinia produced per $50 \mathrm{~mm}^{2}$ per day. Spore production per $50 \mathrm{~mm}^{2}$ per day was calculated using the difference between sporulation 10 and 15 days postinoculation from the $50-\mathrm{mm}^{2}$ inoculation areas for each genotype divided by 5 days. Similarly, number of uredinia produced per $50 \mathrm{~mm}^{2}$ per day was calculated using the difference between the uredinia produced 10 and 15 days postinoculation for each genotype divided by 5 days. The latent period was the average number of days from inoculation until uredinium eruption.

b Isolates of P. pachyrhizi were collected from infected soybean from Citra, FL in 2005. These isolates were used to inoculate one susceptible soybean cultivar ('Mycogen 5N327RR'), seven susceptible kudzu genotypes, and one resistant (red-brown lesions with restricted urediniospore production) kudzu genotype. All variables were recorded 20 days after inoculation in detached leaflets.

c Isolates of P. pachyrhizi from Brazil in 2001, Alabama in 2004, and Louisiana in 2004. All isolates were maintained on susceptible soybean cultivars and, for Bonde et al. (2009), spores were collected periodically and stored in liquid nitrogen for later use. These isolates were used to inoculate whole plants of one susceptible soybean cultivar ('Williams'), 54 susceptible kudzu genotypes, and 27 resistant kudzu genotypes. All variables were averaged across three isolates. Lesion densities were rated on a five-point scale, where $1=$ no lesions, $2=a$ few lesions, $3=$ a light lesion density, $4=$ a moderate lesion density, and $5=a$ heavy lesion density, the last comparable with that of infection on the soybean. Mean number of uredinia per lesion was determined from 25 randomly selected uredinia. The proportion of lesions with sporulating uredinia was rated from 0 to 5 , where $0=$ no lesions sporulating, $1=20 \%$ lesions sporulating, $2=40 \%$ lesions sporulating, $3=60 \%$ lesions sporulating, $4=80 \%$ lesions sporulating, and $5=100 \%$ lesions with uredinia sporulating. 
urediniospores would provide extended protection from the lethal effects of ultraviolet radiation (Isard et al. 2006a). Finally, the primary mechanism that causes deposition of rust spores after longdistance aerial transport is rainfall (Isard et al. 2011; Rowell and Romig 1966). Precipitation can efficiently wash spores from a tall column of air onto a host and concomitantly provide the pathogen with the environmental conditions (leaf wetness and cool to moderate temperatures) required to rapidly infect a plant host (Aylor 1986; Isard and Gage 2001; Rowell and Romig 1966). Research indicates that only approximately $50 \%$ of the spores deposited into canopies by wet and dry deposition can be retained in the lower canopy levels (Fig. 3) (Dufault et al. 2010). However, the retention within these levels is only a small percentage (e.g., optimally approximately 2 to $4 \%$ ) of the spores that are deposited. These numbers are further reduced when considering spore mortality due to ultraviolet radiation and nonoptimal environmental conditions during transport (Isard et al. 2005).

\section{PIPE, SENTINEL PLOT MONITORING, AND FORECASTING}

Pest Information Platform for Extension and Education. The Pest Information Platform for Extension and Education (PIPE) is a network connected by computers using advanced Information Technology (IT) to add value to field observations of agricultural pests (Isard et al. 2006b). Initially, the goal of the system was to enhance support for managing soybean rust in North America. In 2005, the USDA Animal and Plant Health Inspection Service (APHIS) supported the IT platform. The soybean rust PIPE coupled phenological, epidemiological, and aerobiological models with an extensive monitoring network benefited from an unprecedented level of cooperation and coordination among USDA and state agricultural agencies, universities, industry, and grower organizations (Isard et al. 2006b; Sikora et al. 2014). The USDA Economic Research Service concluded that the management decision support provided through the soybean rust PIPE website increased profits

TABLE 2. Characterization of virulence in Phakopsora pachyrhizi populations from different geographic regions and years ${ }^{\mathrm{a}}$

\begin{tabular}{|c|c|c|c|c|c|}
\hline $\begin{array}{l}\text { Origin of } \\
\text { research }\end{array}$ & Origin of isolates & $\begin{array}{c}\text { Number of } \\
\text { isolates tested }\end{array}$ & Lines used & $\begin{array}{c}\text { Races or } \\
\text { pathotypes }\end{array}$ & Reference \\
\hline Taiwan & Taiwan & 9 & $\begin{array}{l}11 \text { legume accessions, } 6 \text { accessions of } \\
\text { soybean, and } 5 \text { Phaseolus spp. }\end{array}$ & 6 & Lin 1966 \\
\hline Australia & Australia & Not known & 'Wills' and PI 200492 & 2 & McLean and Byth 1980 \\
\hline United States & $\begin{array}{l}\text { Australia, India, and } \\
\text { Taiwan }\end{array}$ & 4 & $\begin{array}{l}\text { PI } 200492(\text { Rppl), PI } 230970(R p p 2) \text { and } \\
\text { PI } 462312(R p p 3)\end{array}$ & 4 & Bromfield et al. 1980 \\
\hline Taiwan & Taiwan & 50 & $\begin{array}{l}\text { PI } 200492(R p p 1), \text { PI } 462312(R p p 3) \text {, } \\
\text { PI } 230971, \text { TK\#5, and TN } 4\end{array}$ & 3 & Yeh 1983 \\
\hline Australia & Australia & 8 & $\begin{array}{l}257 \text { accessions of four Glycine spp.: Glycine } \\
\text { canescens }(60), \text { G. clandestine }(63), \\
\text { G. tabacina (100), and G. tomentella (47) }\end{array}$ & 6 & Burdon and Speer 1984 \\
\hline China & China & 7 & $\begin{array}{l}\text { PI } 200492(R p p 1), \text { PI } 462312(R p p 3) \text {, } \\
\text { PI } 459025(R p p 4) \text {, and } 5 \text { other accessions }\end{array}$ & 4 & Tan and Sun 1989 \\
\hline Taiwan & Taiwan & 42 & $\begin{array}{l}\text { AVRDC differential lines: PI } 200492(R p p 1) \text {, } \\
\text { PI } 230970(\text { Rpp2), PI } 462312(R p p 3), \\
\text { PI 230971, PI 239871A, PI } 239871 \mathrm{~B}, \\
\text { PI } 459024 \text { and PI 459025, TK-5, TN-4, and } \\
\text { Wayne }\end{array}$ & 9 & Hartman et al. 2011 \\
\hline Japan & Japan & 45 & AVRDC differential lines & 18 & Yamaoka et al. 2002 \\
\hline South Africa & South Africa & $\begin{array}{l}1 \text { composite field } \\
\text { population }\end{array}$ & AVRDC differential lines & $\begin{array}{l}0 \text { (all the differential } \\
\text { lines were susceptible) }\end{array}$ & $\begin{array}{l}\text { Caldwell and } \\
\text { McLaren } 2004\end{array}$ \\
\hline United States & Multiple & 12 international & $\begin{array}{l}\text { PI } 200492(R p p 1), \text { PI } 230970(R p p 2) \text {, } \\
\text { PI } 462312(R p p 3), \text { and PI 459025B (Rpp4) }\end{array}$ & 6 & Bonde et al. 2006 \\
\hline United States & Multiple & $\begin{array}{l}4 \text { bulked } \\
\text { international }\end{array}$ & $\begin{array}{l}\text { PI } 200492(R p p 1), \text { PI } 230970(R p p 2) \text {, } \\
\text { PI } 462312(R p p 3), \text { PI } 459025 \text { B }(R p p 4) \text {, and }\end{array}$ & 2 & Miles et al. 2006 \\
\hline Paraguay & Paraguay & $\begin{array}{l}1 \text { composite field } \\
\text { population }\end{array}$ & $\begin{array}{l}\text { PI } 462312(\text { Rpp3), PI 459025B (Rpp } 4) \text {, and } \\
528 \text { other accessions }\end{array}$ & 2 & Miles et al. 2008 \\
\hline United States & United States & 6 United States & $\begin{array}{l}\text { PI } 200492(R p p 1), \text { PI 594538A }(R p p 1 b) \text {, } \\
\text { PI } 462312(R p p 3), 459025 B(R p p 4) \text {, and } \\
23 \text { other accessions }\end{array}$ & 2 & Paul and Hartman 2009 \\
\hline United States & Multiple & 10 international & $\begin{array}{l}\text { PI } 200492(R p p 1), \text { PI } 230970(R p p 2) \text {, } \\
\text { PI } 462312(R p p 3), \text { PI } 459025 B(R p p 4) \text {, } \\
\text { and } 16 \text { others }\end{array}$ & 8 & Pham et al. 2009 \\
\hline Nigeria & Nigeria & 116 & $\begin{array}{l}\text { PI } 200492(R p p 1), \text { PI } 230970(R p p 2) \text {, } \\
\text { PI } 462312(R p p 3), \text { PI } 459025 B(R p p 4) \text {, } \\
\text { PI 594538A, UG-5, TGx 1485-1D and } \\
\text { TGx 1844-4F }\end{array}$ & 7 & Twizeyimana et al. 2009 \\
\hline United States & Multiple & 8 international & $\begin{array}{l}\text { PI } 200492(R p p l), \text { PI 594538A }(R p p l b) \text {, } \\
\text { PI 587866, and PI 587880A }\end{array}$ & 3 & Ray et al. 2009 \\
\hline Vietnam & Vietnam & $\begin{array}{l}1 \text { composite field } \\
\text { population }\end{array}$ & $\begin{array}{l}\text { PI } 200492(R p p 1), \text { PI 594538A }(R p p 1 b) \text {, } \\
\text { PI } 462312(R p p 3), 459025 B(R p p 4) \text {, and } \\
85 \text { other accessions }\end{array}$ & 7 & Pham et al. 2010 \\
\hline Brazil & Multiple & 3 & 13 accessions including sources of Rppl-5 & 3 & Yamanaka et al. 2010 \\
\hline United States & Multiple & 8 & $\begin{array}{l}\text { PI } 462312 \text { (Rpp3), Hyuuga (Rpp?), and } 12 \\
\text { other accessions }\end{array}$ & 6 & Kendrick et al. 2011 \\
\hline United States & Multiple & 4 & 34 accessions including sources of Rppl-4 & & Miles et al. 2011 \\
\hline United States & United States & Field populations & $\begin{array}{l}\text { PI } 200492(R p p 1), \text { PI } 230970(R p p 2) \text {, } \\
\text { PI } 462312(\text { Rpp3), PI } 459025 \text { B (Rpp } 4) \text {, and } \\
\text { over } 500 \text { other accessions }\end{array}$ & 2 & Walker et al. 2011 \\
\hline United States & United States & 72 United States & $\begin{array}{l}\text { PI } 200492(R p p 1), \text { PI } 230970(R p p 2) \text {, } \\
\text { PI } 462312(R p p 3), \text { PI } 459025 B(R p p 4) \text {, } \\
\text { PI } 200526(R p p 5) \text {, and three others }\end{array}$ & 3 & $\begin{array}{l}\text { Twizeyimana and } \\
\text { Hartman } 2012\end{array}$ \\
\hline
\end{tabular}

${ }^{a}$ Modified and updated from Hartman et al. (2011). PI = plant introduction and AVRDC = Asian Vegetable Research and Development Center. 
for producers in the United States by $\$ 11$ to 299 million in 2005 (Roberts et al. 2006).

Realizing the success of the IT approach to soybean rust management decision support, the USDA Risk Management Agency (RMA), the National Institute for Food and Agriculture (NIFA) (formerly Cooperative State Research, Extension and Education Service), and APHIS funded the creation of the Integrated Pest Management PIPE (ipmPIPE). The ipmPIPE provided producers with in-season information about the spread of soybean rust and other legume pests and diseases. The United Soybean Board (USB) and North Central Soybean Research Program (NCSRP) contributed substantial support for additional monitoring and dissemination of educational materials to stakeholders (Isard et al. 2006b). The ipmPIPE continued to expand in subsequent years to include components for soybean aphid, legume diseases, cucurbit downy mildew, pecan nut casebearer, southern corn rust, and onion pests (VanKirk et al. 2012). Sites in Canada and Mexico were added to the monitoring network. Use of the Internet platform by producers, crop consultants, extension professionals, and administrators from 2005 to 2010 was high. An analysis by extension professionals indicates that growers' use of the soybean rust component of the platform alone saved \$207 million in fungicide application costs in 2007 (Giesler and Hershman 2007) and approximately \$200 million per year in 2008 and 2009 (Hershman 2009). More than $90 \%$ of 361 Certified Crop Advisors who responded to a survey in 2008 indicated that they valued the soybean rust ipmPIPE website and sentinel plot network, and that they felt
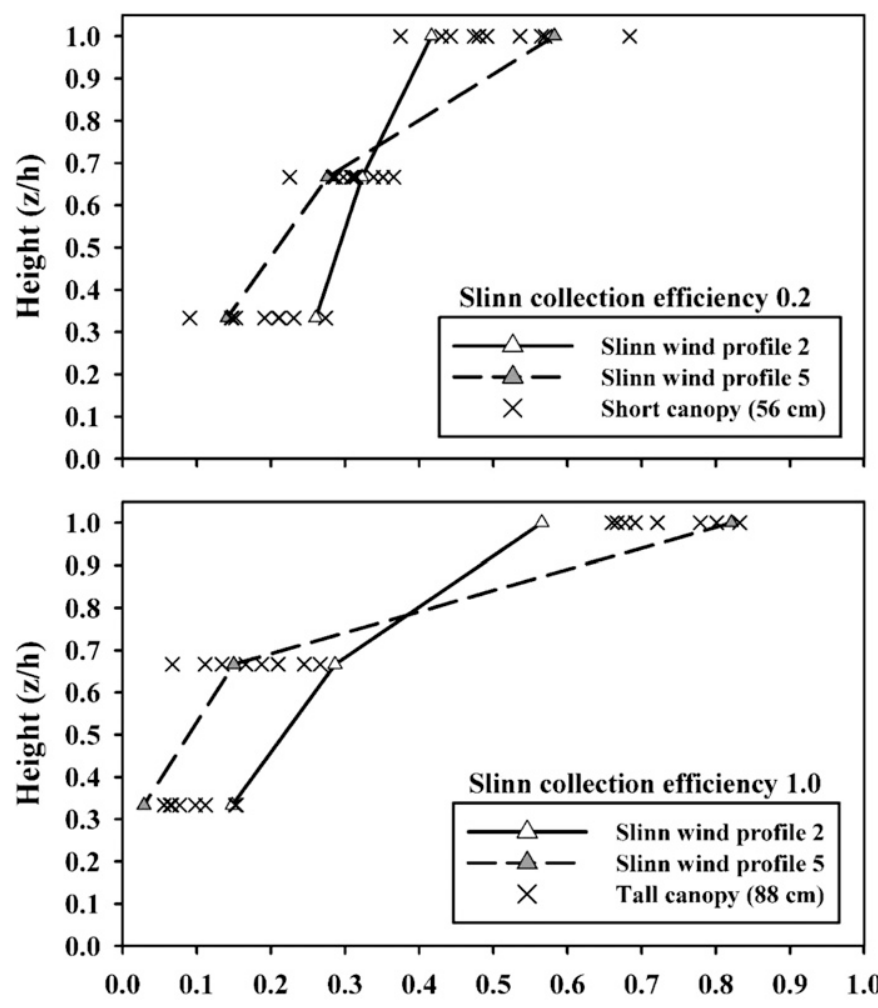

\section{Deposition proportion $\left(\mathbf{X}_{\mathrm{obs}} / \mathbf{X}_{\mathrm{sum}}\right)$}

Fig. 3. Comparison of observed NG-20 particle deposition profiles within soybean canopies to theoretical vertical profiles (Slinn 1982) for particle deposited from the air into vegetative canopies. Deposition profiles observed for the NG-20 particles in the short and tall height treatments are represented by $\mathrm{Xs}$ in the graph. Theoretical particle profiles given by Slinn's equation for the different collection efficiency $(\xi)$ values of 0.2 and 1.0 and wind profile parameters $(\gamma)$ of 2 and 5 are represented by lines and triangles, respectively, in the graph. Height was determined by dividing ' $z$ ' (canopy reference height) by 'h' (average plant canopy height). For these plots $\mu_{\mathrm{r}}=2 \mathrm{u}_{\mathrm{h}}$ in equation 1 . Deposition proportion was calculated by dividing the observation height variable $\left(\mathrm{X}_{\mathrm{obs}}\right)$ by the sum of the variables $\left(\mathrm{X}_{\text {sum }}\right)$ within a single profile. "somewhat" to "very" confident in the information obtained from them (Bradley et al. 2010). The soybean rust component of the PIPE is currently part of the iPiPE system supported by the USB and NIFA.

The IT structure of the soybean rust component of the PIPE involves channeling field observations of the pathogen, its hosts, and the environment through standardized Internet portals into a national database (Isard et al. 2006b). This was accomplished by developing protocols for field monitoring of the pathogen and its hosts and integrating an ever-evolving set of tools, including spreadsheet files, Internet forms, personal digital assistant programs, and, most recently, smart device applications for easy and rapid entry of observations into a national database. Weather products created by the National Weather Service are also downloaded daily and archived. These spatiotemporal-referenced data sets enable users to build and run models on a common Internet platform using near-real-time field observations and both current and forecast environmental data. Outputs from multiple models running on the platform are integrated with field observations of soybean rust into easy-to-read maps that are available to interested stakeholders. Growers, crop advisors, and extension professionals are the primary users of the ipmPIPE system; however, the information also is useful to researchers, agribusiness, and state and federal agencies. The crop insurance industry and the USDA RMA also benefit from the maps and expert commentary, which help them to document pest risk and good pest management practices (VanKirk et al. 2012). Users access information on the PIPE through two interrelated websites. A restricted-access website provides a platform for extension specialists, researchers, and administrators to view and interpret these maps. Extension specialists then use state-of-the-art IT tools to disseminate interpretations, management guidelines, and other relevant materials to growers, their consultants, and industry agents through a publicaccess website.

Sentinel plots. With the first identification of soybean rust in the United States, a network was established to track the occurrences of soybean rust in conjunction with spore-monitoring programs. This network enlisted a large number of agricultural professionals to do field monitoring. In one of the most rapid responses in history, a group of scientists and the soybean commodity check-off organizations developed a program to track the development of soybean rust in 2005 by monitoring fields and sentinel plots. The funding for the network was provided by the NCSRP and the USB. In Canada, the program was funded by the Ontario Ministry of Agriculture, Food, and Rural Affairs in conjunction with Agriculture Canada, and by the Grain Farmers of Ontario. In 2007, the sentinel plots were expanded to include Mexico through Sistema Nacional de Vigilancia Epidemiológica Fitosanitaria and Secretaría de Agricultura, Ganadería, Desarrollo Rural, Pesca y Alimentación. This entire funded network was designed to input monitoring data into ipmPIPE. This allowed extension and research pathologists to design a state-of-the-art field network for direct use by clientele with daily updates.

The sentinel plot network was established in all soybean-growing states and Ontario, Canada in 2005. The number of sentinel plots within each state was based on the hectares of soybean grown in that state. Although sentinel plot specifics varied somewhat, the general design was that plots were to be planted earlier than the commercial soybean fields in southern states, and portions of commercial fields were used as sentinels in many northern states. Each site was a minimum of $15 \mathrm{~m}^{2}$ and was to be repeatedly monitored by close inspection of leaves. Several locations established multiple planting dates to ensure different stages of crop development for scouting purposes. Many university campuses and research centers established sentinel plots to provide a location where plants could be examined routinely with minimal travel expense. In addition, spore monitoring was done by active and passive traps at some locations, and this led to the development of several new techniques for quantifying spores in traps (Schneider and Durr 2012; Schneider et al. 2009a; Vittal et al. 2012a)(Figs. 4 and 5). Over the course of the first few years of monitoring, the use of humidity chambers to 
incubate leaves before inspection with a dissecting microscope became common practice among the collaborators. At its peak in 2007, the sentinel plot program had over 800 monitoring locations with over 2,000 sites, including commercial fields that were scouted, resulting in more than 13,400 uploads to the website (Giesler and Hershman 2007). A list of the primary coordinators in each state and province was published (Sikora et al. 2014). Workshops were utilized to train many of the individuals in this network, and several states coordinated workshops with the University of Florida to ensure firsthand experiences with the disease for personnel who were scouting sentinel plots in locations where soybean rust had not been detected.

The sentinel plot network was inclusive of all soybean-producing areas in North America from 2005 through 2009. In 2010, participants in most northern states stopped looking for soybean rust, and the system was reduced primarily to southern states. Most of the same protocols developed with the initial group are still being implemented, and kudzu surveys are a major part of the monitoring program. This transition resulted in a focused effort that has been valued by the soybean industry in states that are more consistently

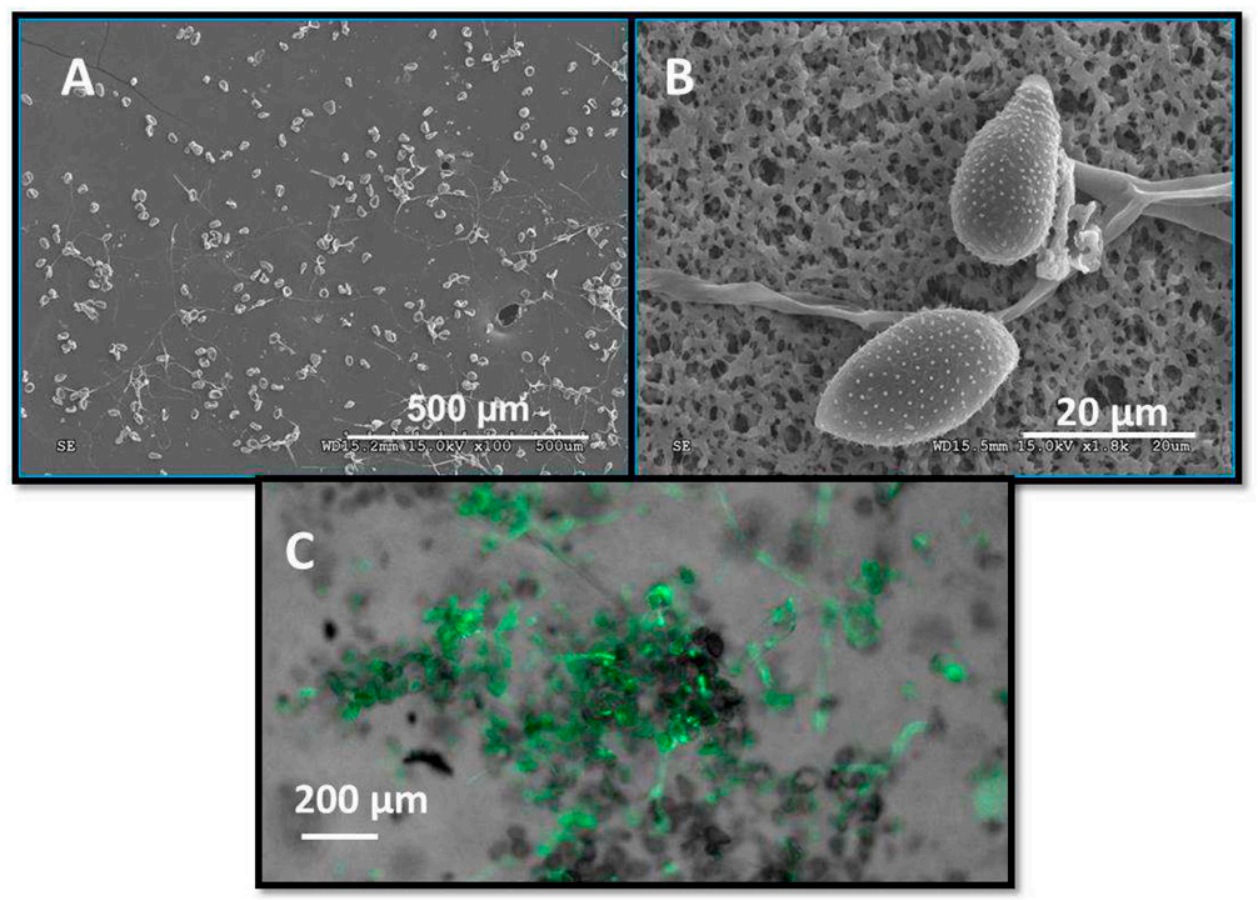

Fig. 4. Urediniospores of Phakopsora pachyrhizi collected with an electrostatic particulate sampler (ionic spore trap) in a soybean field with severe soybean rust. A, Dissecting scope view of membrane on collection stub showing urediniospores, some of which have germinated after incubation in a moist chamber; B, scanning electron microscope view of germinated urediniospores; and $\mathbf{C}$, urediniospores stained with a specific fluorescent antibody and then superimposed with visible light on the same slide.
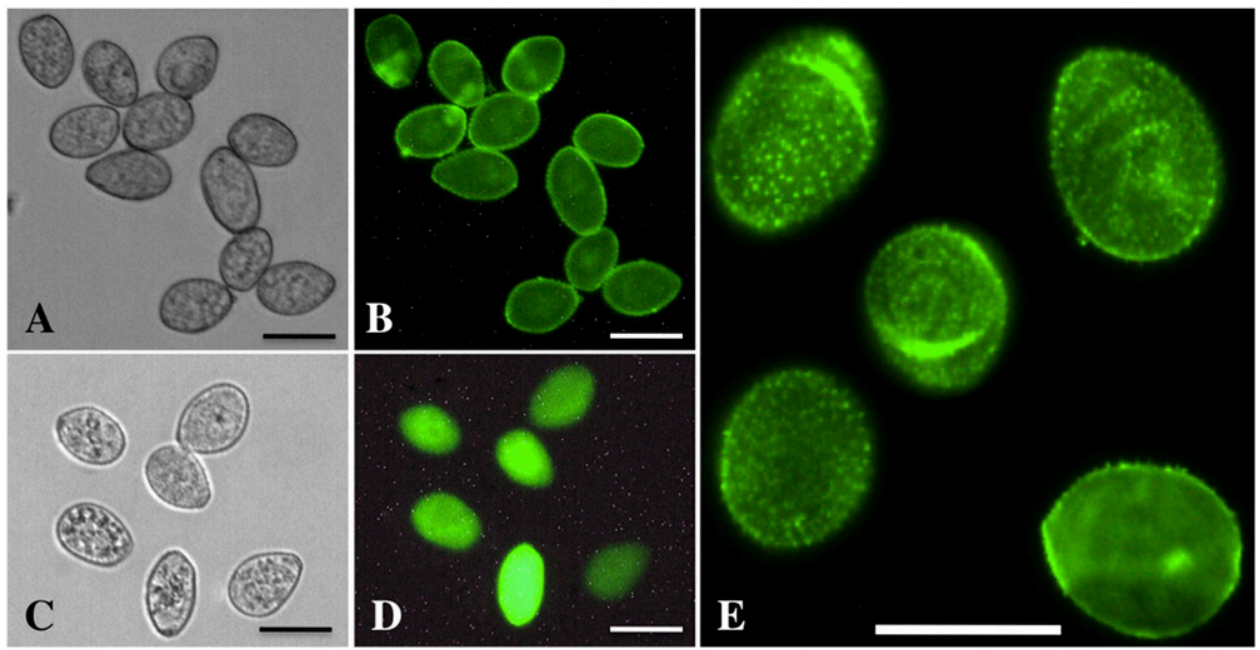

Fig. 5. Detection of urediniospores of Phakopsora pachyrhizi isolate FL07-1 by immunofluorescence. A 1:1 spore mixture consisting of freshly collected live and dead spores (heat-killed at $55^{\circ} \mathrm{C}$ for $10 \mathrm{~h}$ ) were detected. A and B, Indirect immunofluorescence using antirust polyclonal antibodies. $\mathbf{C}$ and $\mathbf{D}$, Direct immunofluorescence using monoclonal antibody $(\mathrm{mAb})$ labeled with fluorescein isothiocyanate (FITC) (FITC-Pp-mAb). E, Echinulations of urediniospores fluorescing green in an indirect immunofluorescence assay using Pp-mAb antibodies. A and C, Visualized using an Olympus BX51 microscope under bright field. B and D, Visualized using an Olympus BX51 microscope under bright field, then under a dual-bandpass filter set for FITC-propidium iodide. Scale bar represents $20 \mu \mathrm{m}$. (From Vittal et al. 2012a). 
experiencing soybean rust or are adjacent to these states. Funding for this effort has continued with USB for those states primarily affected with additional state check-off program funding.

One of the unintended benefits from this program was the collaboration that resulted from so many scientists being involved in a single, focused project (Hershman et al. 2011). This program significantly enhanced interactions among land-grant university plant pathologists, commodity leaders, industry, and state and federal government agencies across the United States as well as scientists in Canada and Mexico. The rapid response and interactions of the individuals involved in the development of this network show the resiliency and readiness of agricultural scientists to actively assist in helping farmers to respond to problems that threaten our global food production. The prodigious number of publications on soybean rust and the progress that has been made across all fronts are a direct result of these interactions and enlightened discussions that occurred, stemming from the need to collectively focus and deliver results.

Forecasting systems. Two very different types of forecasting models were used to predict the aerial movement of $P$. pachyrhizi after its North American incursion: the Integrated Aerobiology Modeling System (IAMS) and the climate-dispersion integrated model system. Both modeling systems rely on observations from the Sentinel Plot Network to demarcate infected counties and soybean rust severity as source input.

The IAMS, developed by scientists from Penn State University and ZedX Inc., is constructed with six modules: spore release and escape from the plant canopy, atmospheric transport, mortality due to exposure to solar radiation, wet and dry deposition of spores, host development at destinations, and disease progress on these hosts. The modeling system predicts the progression and intensity of a soybean rust epidemic in an impacted region and when the spatial unit becomes a source of $P$. pachyrhizi spores for further atmospheric spread. The time step for model simulations is $1 \mathrm{~h}$ and the model domain is 7.5 to $50^{\circ} \mathrm{N}$ latitude and 60 to $130^{\circ} \mathrm{E}$ longitude, with a grid resolution of $0.083^{\circ}$ (approximately $10 \mathrm{~km}$ ) and a vertical resolution defined by the standard pressure levels $(1,000,950,900,850,800,700,600$, and $500 \mathrm{hPa})$. Thus, there are as many as eight three-dimensional "air layers" above each grid cell on the ground. Wind speed and direction, air temperature, humidity, and cloud cover data used in IAMS simulations are from U.S. National Oceanic and Atmospheric Administration (NOAA) National Center for Environmental Prediction and the U.S. National Weather Service NEXRAD Stage IV radar precipitation models. Details of each module have been reported (Isard et al. 2007). The IAMS has been run on a daily basis since spring 2005, and the resulting maps are displayed and archived at the PIPE website.

The climate-dispersion integrated model, constructed by researchers from Iowa State and St. Louis Universities (Pan et al. 2006), integrates the particle transport and dispersion components of the NOAA Air Resource Lab HYSPLIT_4 model (Draxler and Hess 1998) with the Pennsylvania State University/National Center for Atmospheric Research mesoscale MM5 regional climate prediction model (Dudhia and Bresch 2002). The resulting forecasting system was used to predict the trajectory and concentration of spores of $P$. pachyrhizi based on three-dimensional wind advection and turbulent transport. The model incorporates a simple viability criterion for aerial spores as well as both wet and dry deposition, and it was configured with a domain that included the southeastern United States with a resolution of $40 \mathrm{~km}$. The modeling system was used to predict spore movement in the southeastern United States a month in advance during the 2005 to 2007 growing seasons (Pan et al. 2006; Yang et al. 2007).

\section{SOYBEAN RUST MANAGEMENT}

Management of $\boldsymbol{P}$. pachyrhizi through resistance breeding. Even before soybean rust was reported in the United States, evaluation of soybean plant introductions (PIs) and commercial cultivars was part of the mission of the USDA-ARS FDWSRU. In a cooperative effort with USDA-ARS scientists at the Urbana, IL location, over 17,000 entries, mostly PIs from the USDA Soybean Germplasm Collection and some commercial soybean cultivars, were tested for resistance to P. pachyrhizi; 805 PIs were designated for retesting because of their potential resistance (Miles et al. 2006). Of these 805 PIs, a subset of 530 was evaluated in Paraguay during the 2005-06 growing season, in which 16 PIs were identified with field resistance (Miles et al. 2008). With the discovery of soybean rust in the United States in 2004, more effort was placed on field screening of PIs and genetic studies in the United States. These evaluations led to the development and release of soybean rustresistant germplasm (Boerma et al. 2011; Diers et al. 2013; Paul et al. 2010). Although there are no commercially available soybean cultivars with soybean rust resistance in the United States, these early releases and breeding lines that are being evaluated will lead to cultivar releases in the near future, including some with at least two Rpp genes.

In a more historical context from the 1970s and 1980s, there were studies conducted at the Asian Vegetable Research and Development Center in Taiwan, the University of Queensland in Australia, and in the United States (USDA-ARS FDWSRU) that identified major genes conditioning resistance in PIs 200492, 230970, 462312, and 459025B named Rppl through Rpp4, respectively (Table 3). These genes were later genetically mapped to independent loci on three different chromosomes (Hyten et al. 2007, 2009; Silva et al. 2008).

After P. pachyrhizi was detected in South America in 2001, researchers in Brazil identified additional soybean germplasm accessions with resistance genes at a fifth locus (Garcia et al. 2008; Table 3). At least four different resistance alleles, including two recessive rpp genes, have been mapped to the Rpp5 locus in several other soybean PIs (Calvo et al. 2008; Garcia et al. 2008). A sixth gene (Rpp6) was identified by Li et al. (2012), and at least eight other Rpp loci have been claimed in United States patents and patent applications (e.g., U.S. Patents 8,389,798; 8,669,414; and 8,692,054). The soybean loci Rppl through Rpp6 segregate independently, though Rpp1, Rpp4, and Rpp6 are all on chromosome 18 (Table 3).

TABLE 3. Soybean rust resistance (Rpp) genes and sources; genes with the same number are thought to be allelic

\begin{tabular}{|c|c|c|c|c|}
\hline Gene & Source of PI & Chromosome/linkage group & Origin of PI & Reference \\
\hline Rppl & PI 200492 ('Komata') & $18 / \mathrm{G}$ & Shikoku, Japan & Hyten et al. 2007; McLean and Byth, 1980 \\
\hline$R p p 1-b$ & PI 594538A & $18 / \mathrm{G}$ & Fujian, China & Chakraborty et al. 2009; Miles et al. 2008 \\
\hline Rpp2 & PI 230970 & $16 / \mathrm{J}$ & Japan & Bromfield et al. 1980; Silva et al. 2008 \\
\hline rpp2 (PI 224270) & PI 224270 & $16 / \mathrm{J}$ & Hyogo, Japan & Garcia et al. 2008 \\
\hline Rpp3 & PI 462312 ('Ankur') & $6 / \mathrm{C} 2$ & Uttar Pradesh, India & Bromfield et al. 1980; Hyten et al. 2009 \\
\hline Rpp4 & PI 459025B ('Bing Nan') & $18 / \mathrm{G}$ & Fujian, China & Hartwig, 1986; Silva et al. 2008 \\
\hline Rpp5 (PI 200487) & PI 200487 & $3 / \mathrm{N}$ & Shikoku, Japan & Garcia et al. 2008; Pierozzi et al. 2008 \\
\hline Rpp5 (PI 200526) & PI 200526 & $3 / \mathrm{N}$ & Shikoku, Japan & Garcia et al. 2008; Pierozzi et al. 2008 \\
\hline Rpp5 (PI 471904) & PI 471904 & $3 / \mathrm{N}$ & Java, Indonesia & Garcia et al. 2008 \\
\hline rpp5 (PI 200456) & PI 200456 & $3 / \mathrm{N}$ & Shikoku, Japan & Garcia et al. 2008 \\
\hline Rpp6 & PI 567102B & $18 / \mathrm{G}$ & East Java, Indonesia & Miles et al. 2006; Li et al. 2012 \\
\hline
\end{tabular}

${ }^{a}$ Modified and updated from Hartman et al. (2011). PI = plant introduction. 
Multiple resistance gene alleles have been mapped to the Rpp1, Rpp3, and Rpp5 loci (Garcia et al. 2008; Hossain et al. 2015), and some alleles that condition a high level of resistance to fungal populations and isolates from one continent are entirely ineffective against those from another (Walker et al. 2014b). The Rpp6 gene is unusual in that it has provided a high level of resistance to numerous field populations and isolates from North and South America (Li et al. 2012; Miles et al. 2008; Walker et al. 2011, 2014a,b), though some populations or isolates have been able to overcome Rpp6-based resistance (Paul et al. 2013; Walker et al. 2014b). In addition, Japanese 'Hyuuga' soybean was found to have two resistance genes at the Rpp3 and Rpp5 loci (Kendrick et al. 2011).

Soybean cultivars with resistance to $P$. pachyrhizi would be a valuable component in a sustainable soybean rust management program. The development of soybean cultivars with broad resistance to $P$. pachyrhizi has been complicated by extensive pathogen diversity (Table 2), and the ability of the fungus to evolve genetic diversity despite the apparent lack of a sexual stage (Vittal et al. 2012b) contributes to temporal and geographic differences and shifts in the pathogenicity of $P$. pachyrhizi populations (Akamatsu et al. 2013; Paul et al. 2013; Walker et al. 2014a).

Management of soybean rust through fungicide applications. A review article summarized the use of foliar fungicides to control soybean rust, primarily in Asia, before 2003 (Miles et al. 2003b). Between 2002 and 2005, coordinated fungicide efficacy trials were conducted in both South America and southern Africa that tested curative and protectant products and their mixtures, along with single and multiple applications to evaluate products, rates, and the number of applications needed to control soybean rust and maintain soybean yields (Miles et al. 2007). Much of this research was the basis for registering fungicide products in the United States after 2004. To help growers, consultants, and extension educators, a manual on using foliar fungicides to manage soybean rust was published (Dorrance et al. 2008).

In 2005, there were concerns in the United States related to fungicide availability, spray equipment and operators, and application timing. Previous to 2005, foliar fungicide use on soybean in the United States was limited primarily to the Southeast and midSouth to manage late-season foliar diseases such as frogeye leaf spot and Cercospora leaf blight. With the occurrence of soybean rust, producers would have to apply fungicides earlier in the season (Mueller et al. 2009; Schneider et al. 2009b). Soybean rust epidemics often are explosive and effective fungicide use relies on when fungicide is applied (before or after rust observation) and the type of product (curative or protectant) (Fig. 6). In general, the initial fungicide application would be applied soon after flowering or when rust is first observed in the field or area. This may be followed up by an additional application 2 to 4 weeks later (Sikora et al. 2009). Scouting is important to determine the timing for these applications.

The soybean sentinel plot system helps producers by providing a support tool for scouting and for management decisions related to fungicide application timing (Allen et al. 2014; Sikora et al. 2009). Using this tool, many southern producers are able to determine if there is a need for an early-season fungicide application. Sentinel plots have allowed growers to monitor the movement of soybean rust each year and have made the decision of when to apply fungicides a more rational process.

Although fungicides can be effective in controlling soybean rust, there are still concerns related to the overuse of these fungicides which could result in strains of $P$. pachyrhizi becoming insensitive or resistant to a fungicide, as was reported in Brazil (Godoy 2012). Another concern that complicates fungicide application timing is the fact that $P$. pachyrhizi may, under some circumstances, have an extended latent period (up to 60 days) that would complicate the timing and use of curative and protective fungicides (Schneider et al. 2009b; Ward et al. 2012). In summary, both host resistance and fungicide applications are major components to an integrated management strategy but there may be other considerations that may influence the severity of a rust epidemic, including planting dates and cultivar maturity.

\section{COORDINATED RESEARCH EFFORTS}

Much of the success of managing soybean rust and obtaining research information about the disease in the United States has come through cooperative efforts among researchers. One example of this cooperation has been the research hub at the University of Florida North Florida Research and Education Center (NFREC) in Quincy. With funding from the NCSRP, USB, and USDA-ARS, scientists at the NFREC conducted training workshops (over 700 participants), evaluated chemical and biological agents for efficacy on rust, investigated the biology and epidemiology of the pathogen and disease, and participated in research on evaluating soybean for sources of resistance.

The NFREC has very consistently experienced high disease pressure for soybean rust. The NFREC is in the panhandle of Florida, approximately 70 kilometers from the Gulf of Mexico. The typical growing season climate is daily high temperatures of 30 to $35^{\circ} \mathrm{C}$ with high humidity, with regular afternoon thunderstorms. Along with the weather being conducive for rust development, especially in later summer and fall seasons, winters are typically mild, with few freezing episodes. This allows for the survival of rust spores on kudzu. Also, the mild winters do not kill kudzu back to the ground as in more northern areas, and aerial vines quickly produce leaves in the early spring, often infected with soybean rust. This green bridge in the Southeast assures that soybean rust will survive in North America.

\section{CONCLUSION}

The emergence of $P$. pachyrhizi in the Western Hemisphere and its discovery in 2004 in the United States provided the impetuous for a major coordinated research effort that included the areas of basic pathogen biology, epidemiology, and rust management. There have been more refereed journal articles published on soybean rust in the last 10 years than the previous 90 years. This wealth of information benefits not only the scientific community but also the farming community and, more specifically, soybean growers. The coordinated efforts of researchers in the United States at a variety of institutions in many states has resulted in the development of proven management techniques, and the success of the PIPE system for monitoring and reporting the spread of soybean rust each year has made it a paradigm for how to deal effectively with emerging diseases and pests. Although soybean producers have to make many

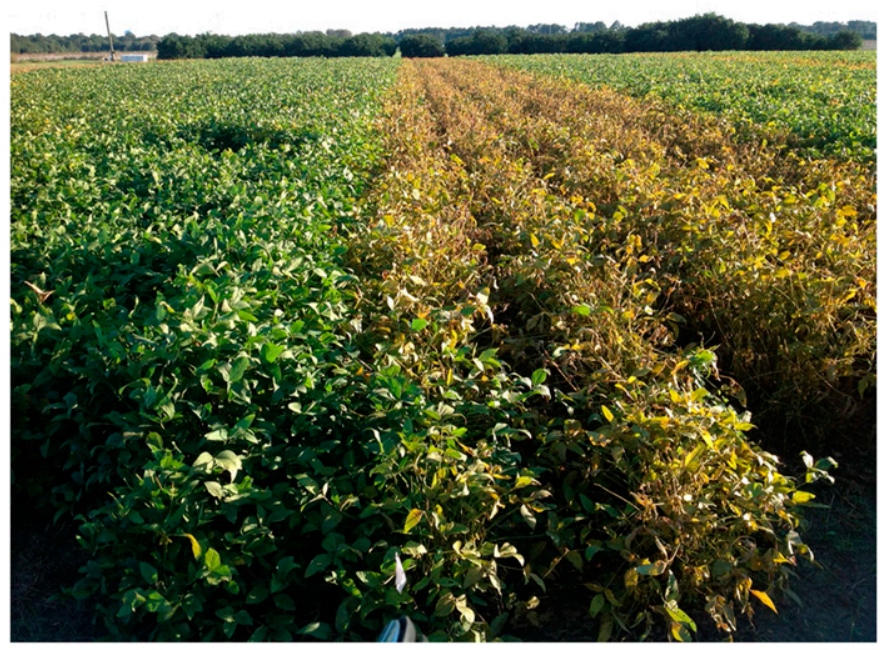

Fig. 6. Soybean plants maturing early due to soybean rust (center) while plants on the either side are maturing at a normal rate and have been sprayed with two applications of a curative fungicide (Courtesy E. J. Sikora; from Hartman et al. 2015). 
management decisions (cultivar selection, rotation, fertility, planting dates, herbicides, and so on), their concerns with soybean rust are less of burden now than 10 years ago, when growers and scientists were very concerned about the impact of soybean rust on soybean production.

\section{LITERATURE CITED}

Akamatsu, H., Yamanaka, N., Yamaoka, Y., Soares, R. M., Morel, W., Ivanovich, A. J. G., Bogado, A. N., Kato, M., Yorinori, J. T., and Suenaga, K. 2013. Pathogenic diversity of soybean rust in Argentina, Brazil, and Paraguay. J. Gen. Plant Pathol. 79:28-40.

Allen, T. W., Hollier, C. A., and Sikora, E. J. 2014. A continuing saga: Soybean rust in the continental United States, 2004 to 2013. Outlooks Pest Manage. 25:167-174.

Andrade, D., Pan, Z., Dannevik, W., and Zidek, J. 2009. Modeling soybean rust spore escape from infected canopies: Model description and results. J. Appl. Meteorol. Climatol. 48:789-803.

Aylor, D. E. 1986. A framework for examining inter-regional aerial transport of fungal spores. Agric. For. Meteorol. 38:263-288.

Boerma, H. R., Monteros, M. J., Ha, B.-K., Wood, E. D., Phillips, D. V., Walker, D. R., and Missaoui, A. M. 2011. Registration of Asian soybean rust-resistant soybean germplasm G01-PR16. J. Plant Registr. 5:118-122.

Bonde, M. R., Melching, J. S., and Bromfield, K. R. 1976. Histology of the suspect-pathogen relationship between Glycine max and Phakopsora pachyrhizi, the cause of soybean rust. Phytopathology 66:1290-1294.

Bonde, M. R., Nester, S. E., Austin, C. N., Stone, C. L., Frederick, R. D., Hartman, G. L., and Miles, M. R. 2006. Evaluation of virulence of Phakopsora pachyrhizi and P. meibomiae isolates. Plant Dis. 90:708-716.

Bonde, M. R., Nester, S. E., Moore, W. F., and Allen, T. W. 2009. Comparative susceptibility of kudzu accessions from the southeastern United States to infection by Phakopsora pachyrhizi. Plant Dis. 93:593-598.

Bonde, M. R., and Peterson, G. L. 1995. Research at the USDA, ARS Containment Facility on soybean rust and its causal agent. Pages 12-18 in: Proc. Soybean Rust Workshop. J. B. Sinclair and G. L. Hartman, eds. College of Agricultural, Consumer, and Environmental Sciences, National Soybean Research Laboratory, Urbana, IL.

Bradley, C. A., Allen, T. W., Dorrance, A. E., Dunphy, E. J., Giesler, L. J., Hershman, D. E., Hollier, C. A., Horn, V., and Wrather, J. A. 2010. Evaluation of the soybean rust pest information platform for extension and education (PIPE) public website's impact on certified crop advisers. Online publication. Plant Health Prog.

Bromfield, K. R. 1984. Soybean Rust Monograph, No. 11. American Phytopathological Society, St. Paul, MN

Bromfield, K. R., Melching, J. S., and Kingsolver, C. H. 1980. Virulence and aggressiveness of Phakopsora pachyrhizi isolates causing soybean rust. Phytopathology 70:17-21.

Burdon, J. J., and Speer, S. S. 1984. A set of differential Glycine hosts for the identification of races of Phakopsora pachyrhizi Syd. Euphytica 33: 891-896.

Caldwell, P. M., and McLaren, N. W. 2004. Soybean rust research in South Africa. Pages 354-360 in: Proc. VII World Soybean Res. Conf., IV Int. Soybean Processing and Utilization Conf., III Congresso Mundial de Soja (Brazilian Soybean Conference).

Calvo, É. S., Kiihl, R. A. S., Garcia, A., Harada, A., and Hiromoto, D. M. 2008. Two major recessive soybean genes conferring soybean rust resistance. Crop Sci. 48:1350-1354

Chakraborty, N., Curley, J., Frederick, R. D., Hyten, D. L., Nelson, R. L., Hartman, G. L., and Diers, B. W. 2009. Mapping and confirmation of a new allele at Rpp1 from soybean PI 504538A conferring RB lesion type resistance to soybean rust. Crop Sci. 49:783-790.

Chang, H.-X., Miller, L. A., and Hartman, G. L. 2014. Melanin-independent accumulation of turgor pressure in appressoria of Phakopsora pachyrhizi. Phytopathology 104:977-984.

Christiano, R. C. S., and Scherm, H. 2007. Quantitative aspects of the spread of Asian soybean rust in the southeastern United States, 2005 to 2006. Phytopathology 97:1428-1433.

Diers, B. W., Kim, K.-S., Frederick, R. D., Hartman, G. L., Unfried, J., Shultz, S., and Cary, T. 2013. Registration of eight soybean germplasm lines resistant to soybean rust. J. Plant Registr. 8:96-101.

Dorrance, A. E., Draper, M. A., and Hershman, D. E., eds. 2008. Using foliar fungicides to manage soybean rust. Land-Grant Univ. Coop. NCERA-208 and OMAF, Bull. SR-2008.

Draxler, R. R., and Hess, G. D. 1998. An overview of the HYSPLIT_4 modeling system of trajectories, dispersion and deposition. Aust. Meteorol. Mag. 47:295-308.

Dudhia, J., and Bresch, J. F. 2002. A global version of the PSU-NCAR mesoscale model. Monthly Weather Rev. 130:2989-3007.
Dufault, N. S., Isard, S. A., Marois, J. J., and Wright, D. L. 2010. The influence of rainfall intensity and soybean plant row spacing on the vertical distribution of wet deposited Phakopsora pachyrhizi urediniospores. Can. J. Plant Pathol. 32:162-169.

Edwards, H., and Bonde, M. R. 2011. Penetration and establishment of Phakopsora pachyrhizi in soybean leaves as observed by transmission electron microscopy. Phytopathology 101:894-900.

Fabiszewski, A. M., Umbanhowar, J., and Mitchell, C. E. 2010. Modeling landscape-scale pathogen spillover between domesticated and wild hosts: Asian soybean rust and kudzu. Ecol. Appl. 20:582-592.

Garcia, A., Calvo, É. S., Kiihl, R. A. S., Harada, A., Hiromoto, D. M., and Veira, L. G. E. 2008. Molecular mapping of soybean rust (Phakopsora pachyrhizi) resistance genes: Discovery of a novel locus and alleles. Theor. Appl. Genet. 117:545-553.

Giesler, L. J., and Hershman, D. E. 2007. Overview and value of sentinel plots for 2007. In: 2nd Natl. SBR Symp. American Phytopathology Society, St. Louis. Online publication. http://www.plantmanagementnetwork.org/ infocenter/topic/soybeanrust/2007/presentations/Giesler.pdf

Godoy, C. V. 2012. Risk and management of fungicide resistance in the Asian soybean rust fungus Phakopsora pachyrhizi. Pages 87-95 in: Fungicide Resistance in Crop Production: Risk and Management. T. S. Thind, ed. CAB International, Wallingford, UK

Gregory, P. H. 1973. The Microbiology of the Atmosphere. John Wiley and Sons, New York.

Gumpert, F. M. 1989. Measuring disease progress in pure and mixed stands of plant cultivars. Phytopathology 79:968-973.

Harmon, C. L., Harmon, P. F., Mueller, T. A., Marois, J. J., and Hartman, G. L. 2006. First report of Phakopsora pachyrhizi telia on kudzu in the United States. Plant Dis. 90:380.

Hartman, G. L., Hill, C. B., Twizeyimana, M., Miles, M. R., and Bandyopadhyay, R. 2011. Interaction of soybean and Phakopsora pachyrhizi, the cause of soybean rust. CAB Reviews: Perspectives in Agriculture, Veterinary Science. Nutr. Nat. Resour. 6:1-13.

Hartman, G. L., Rupe, J. C., Sikora, E. F., Domier, L. L., Davis, J. A., and Steffey, K. L. 2015. Compendium of Soybean Diseases and Pests. American Phytopathological Society, St. Paul, MN.

Hartwig, E. E. 1986. Identification of a 4th major gene conferring resistance to soybean rust. Crop Sci. 26:1135-1136.

Haudenshield, J. S., and Hartman, G. L. 2015. Archaeophytopathology of Phakopsora pachyrhizi, the soybean rust pathogen. Plant Dis. (99) In press.

Hennings, V. P. 1903. [A few new Japanese Uredinaceae] Hedwigia 42: S107-S108.

Hershman, D. E. 2009. Changes in 2010 sentinel plot system. In: 3rd Natl. Soybean Rust Symp. American Phytopathology Society, St. Louis.

Hershman, D. E., Sikora, E. J., and Giesler, L. J. 2011. Soybean rust PIPE: Past, present, and future. J. Integr. Pest Manage. 2:D1-D7.

Hoppe, H., and Koch, E. 1989. Defense reactions in host and nonhost plants against the soybean rust fungus (Phakopsora pachyrhizi Syd.). J. Phytopathol. 125:77-88

Hossain, M. M., Akamatsu, H., Morishita, M., Mori, T., Yamaoka, Y., Suenaga, K., Soares, R. M., Bogado, A. N., Ivanovich, A. J. G., and Yamanaka, N. 2015. Molecular mapping of Asian soybean rust resistance in soybean land races PI 594767A, PI 587905 and PI 416764. Plant Pathol. 64: 147-156.

Hyten, D. L., Hartman, G. L., Nelson, R. L., Frederick, R. D., Concibido, V. C., Narvel, J. M., and Cregan, P. B. 2007. Map location of the Rpp1 locus that confers resistance to soybean rust in soybean. Crop Sci. 47: 837-840.

Hyten, D. L., Smith, J. R., Frederick, R. D., Tucker, M. L., Song, Q., and Cregan, P. B. 2009. Bulked segregate analysis using the GoldenGate assay to locate the Rpp3 locus that confers resistance to Phakopsora pachyrhizi (soybean rust) in soybean. Crop Sci. 49:265-271.

Isard, S. A., Barnes, C. W., Hambleton, S., Ariatti, A., Russo, J. M., Tenuta, A., Gay, D. A., and Szabo, L. J. 2011. Predicting seasonal soybean rust incursions into the North American continental interior using sentinel plot monitoring, spore trapping, and aerobiological modeling. Plant Dis. 95: 1346-1357.

Isard, S. A., Dufault, N. S., Miles, M. R., Hartman, G. L., Russo, J. M., De Wolf, E. D., and Morel, W. 2006a. The effect of solar irradiance on the mortality of Phakopsora pachyrhizi urediniospores. Plant Dis. 90:941-945.

Isard, S. A., and Gage, S. H. 2001. Flow of Life in the Atmosphere: An Airscape Approach to Understanding Invasive Organisms. Michigan State University Press, East Lansing, MI.

Isard, S. A., Gage, S. H., Comtois, P., and Russo, J. M. 2005. Principles of the atmospheric pathway for invasive species applied to soybean rust. Bioscience 55:851-861.

Isard, S. A., Russo, J. M., and Ariatti, A. 2007. Aerial transport of SBR spores into the Ohio River Valley during September 2006. Aerobiologia $23: 271-282$ 
Isard, S. A., Russo, J. M., and DeWolf, E. D. 2006b. The establishment of a national pest information platform for extension and education. Online publication. Plant Health Prog.

Javid, I., and Ashraf, M. 1978. Some observations on soybean diseases in Zambia and occurrence of Pyrenochaeta glycines on certain varieties. Plant Dis. Rep. 62:46-47.

Jordan, S. A., Mailhot, D. J., Gevens, A. J., Marois, J. J., Wright, D. L., Harmon, C. L., and Harmon, P. F. 2010. Characterization of kudzu (Pueraria spp.) resistance to Phakopsora pachyrhizi, the causal agent of soybean rust. Phytopathology 100:941-948.

Jurick, W. M., Narváez, D. F., Brennan, M. M., Harmon, C. L., Marois, J. J., Wright, D. L., and Harmon, P. F. 2008. Winter survival of the soybean rust pathogen, Phakopsora pachyrhizi, in Florida. Plant Dis. 92:1551-1558.

Kendrick, M. D., Harris, D. K., Ha, B.-K., Hyten, D. L., Cregan, P. B., Frederick, R. D., Boerma, H. R., and Pedley, K. F. 2011. Identification of a second Asian soybean rust resistance gene in Hyuuga soybean. Phytopathology 101:535-543.

Killgore, E., Heu, R., and Gardner, D. E. 1994. First report of soybean rust in Hawaii. Plant Dis. 78:1216.

Koch, E., Ebrahim Nesbat, F., and Hoppe, H. H. 1983. Light and electron microscopic studies on the development of soybean rust (Phakopsora pachyrhizi Syd.) in susceptible soybean leaves. Phytopathol. Z. 106: 302-320

Li, S., Smith, J. R., Ray, J. D., and Frederick, R. D. 2012. Identification of a new soybean rust resistance gene in PI 567102B. Theor. Appl. Genet. 125:133-142.

Lin, S. Y. 1966. Studies on the physiologic races of soybean rust fungus, Phakopsora pachyrhizi Syd. J. Taiwan Agric. Res. 15:24-28.

Marchetti, M. A., Urecker, F. A., and Bromfield, K. R. 1975. Uredial development of Phakopsora pachyrhizi in soybeans. Phytopathology 65:822-823.

McLean, R. J. 1979. Histological studies of resistance to soybean rust, Phakopsora pachyrhizi. Syd. Aust. J. Agric. Res. 30:77-84.

McLean, R. J., and Byth, D. E. 1980. Inheritance of resistance to soybean rust (Phakopsora pachyrhizi) in soybeans. Aust. J. Agric. Res. 31:951-956.

Melching, J. S., Dowler, W. M., Koogle, D. L., and Royer, M. H. 1989. Effects of duration, frequency, and temperature of leaf wetness periods on soybean rust. Plant Dis. 73:117-122.

Miles, M. R., Bonde, M. R., Nester, S. E., Berner, D. K., Frederick, R. D., and Hartman, G. L. 2011. Characterizing resistance to Phakopsora pachyrhizi. Plant Dis. 95:577-581.

Miles, M. R., Frederick, R. D., and Hartman, G. L. 2003a. Soybean rust: Is the U.S. soybean crop at risk? APSnet Features. Online publication.

Miles, M. R., Frederick, R. D., and Hartman, G. L. 2006. Evaluation of soybean germplasm for resistance to Phakopsora pachyrhizi. Online publication. Plant Health Prog.

Miles, M. R., Hartman, G. L., Levy, C., and Morel, W. 2003b. Current status of soybean rust control by fungicides. Pestic. Outlook 14:197-200.

Miles, M. R., Levy, C., Morel, W., Mueller, T., Steinlage, T., van Rij, N., Frederick, R. D., and Hartman, G. L. 2007. International fungicide efficacy trials for the management of soybean rust. Plant Dis. 91:1450-1458.

Miles, M. R., Morel, W., Ray, J. D., Smith, J. R., Fredierick, R. D., and Hartman, G. L. 2008. Adult plant evaluation of soybean accessions for resistance to Phakopsora pachyrhizi in the field and greenhouse in Paraguay. Plant Dis. 92:96-105.

Mueller, T. A., Miles, M. R., Morel, W., Marios, J. J., Wright, D. L., Kemerait, R. C., Levy, C., and Hartman, G. L. 2009. Effect of fungicide and timing of application on soybean rust severity and yield. Plant Dis. 93:243-248.

Mundt, C. C., Wallace, L. D., Allen, T. W., Hollier, C. A., Kemerait, R. C., and Sikora, E. J. 2014. Initial epidemic area is strongly associated with the yearly extent of soybean rust spread in North America. Biol. Invas. 15:1431-1438.

Murithi, H. H., Beed, F., Soko, M., Haudenshield, J. S., and Hartman, G. L. 2015. First report of Phakopsora pachyrhizi on soybean causing rust in Malawi. Plant Dis. 99:420.2.

Ono, Y., Buritica, P., and Hennen, J. F. 1992. Delimitation of Phakopsora, Physopella and Cerotelium and their species on Leguminosae. Mycol. Res. 96:825-850

Pan, Z., Yang, X. B., Pivonia, S., Xue, L., Pasken, R., and Roads, J. 2006. Long-term prediction of SBR entry into the continental United States. Plant Dis. 90:840-846.

Paul, C., Bowen, C. R., Bandyopadhyay, R., Tefera, H., Adeleke, R., Sikora, E., Pegues, M. D., and Hartman, G. L. 2010. Registration of three soybean germplasm lines resistant to Phakopsora pachyrhizi (soybean rust). J. Plant Registr. 4:244-248.

Paul, C., and Hartman, G. L. 2009. Sources of soybean rust resistance challenged with single-spored isolates of Phakopsora pachyrhizi collected from the USA. Crop Sci. 49:1781-1785.

Pham, T. A., Hill, C. B., Miles, M. R., Nguyen, B. T., Vu, T. T., Vuong, T. D., VanToai, T. T., Nguyen, H. T., and Hartman, G. L. 2010. Evaluation of soybean for resistance to soybean rust in Vietnam. Field Crop Res. 117: 131-138.
Pierozzi, P. H. B., Ribeiro, A. S., Moreira, J. U. V., Laperuta, L. D. C., Rachid, B. F., Lima, W. F., Arias, C. A. A., Oliveira, M. F., and Toledo, J. F. F. 2008. New soybean (Glycine max Fabales, Fabaceae) sources of qualitative genetic resistance to Asian soybean rust caused by Phakopsora pachyrhizi (Uredinales, Phakopsoraceae). Genet. Mol. Biol. 31:505-511.

Pivonia, S., and Yang, X. B. 2004. Assessment of the potential year-round establishment of soybean rust throughout the world. Plant Dis. 88:523-529.

Pivonia, S., and Yang, X. B. 2006. Relating epidemic progress from a general disease model to seasonal appearance time of rusts in the United States: Implications for soybean rust. Phytopathology 96:400-407.

Ray, J. D., Morel, W., Smith, J. R., Frederick, R. D., and Miles, M. R. 2009. Genetics and mapping of adult plant rust resistance in soybean PI 587886 and PI 587880A. Theor. Appl. Genet. 119:271-280.

Roberts, M. J., Schimmelpfennig, D., Ashley, E., and Livingston, M. 2006. The value of plant disease early-warning systems: A case study of USDA's SBR coordinated framework. U. S. D. Agric. Econ. Res. Serv. Econ. Res. Rep. No. 18. Online publication. http://www.ers.usda.gov/media/330972/ err18_1_.pdf

Rowell, J. B., and Romig, R. W. 1966. Detection of urediospores of wheat rusts in spring rains. Phytopathology 56:807-811.

Schneider, R. W., and Durr, E. 2012. Airborne Particulate Sampler. US Patent and Trademark Office. Patent No. US 8,167,986 B2.

Schneider, R. W., Haudenshield, J. S., Hartman, G. L., and Mahaffee, W. F. 2009a. Development and use of fluorescent antibody and qPCR protocols for the electrostatic spore trap. (Abstr.) Phytopathology 99:S115.

Schneider, R. W., Hollier, C. A., Whitam, H. K., Palm, M. E., and McKemy, J. M. 2005. First report of soybean rust caused by Phakopsora pachyrhizi in the continental United States. Plant Dis. 89:774.

Schneider, R. W., Ward, N. A., Robertson, C. L., and Mumma, E. P. 2009b. Latent infection, fungicide efficacy and the need for predictive models. In: 2009 Natl. Soybean Rust Symp. New Orleans. Online publication. http:// www.plantmanagementnetwork.org/infocenter/topic/soybeanrust/2009/

Sconyers, L. E., Kermerait, R. C., Brock, J., Phillips, D. V., Jost, P. H., Sikora, E. J., Gutierrez-Estrada, A., Mueller, J. D., Marois, J. J., Wright, D. L., and Harmon, C. L. 2006. Asian soybean rust development in 2005: A perspective from the Southeastern United States. APSnet Feature. Online publication. https://www.apsnet.org/publications/apsnetfeatures/Pages/ SoybeanRustDev.aspx

Sikora, E. J. 2014. Kudzu, the vine harboring the soybean rust pathogen in the United States: Invasive weed supports soybean rust pathogen through winter months in southeastern United States. Outlooks Pest Manage. 25:175-179.

Sikora, E. J., Allen, T. W., Wise, K. A., Baniecki, J., Bergstrom, G., Bradley, C., Brown-Rytlewski, D., Chilvers, M., Coker, C., Damicone, J., DeWolf, E., Dorrance, A., Dufault, N., Esker, P., Faske, T., Giesler, L., Grau, C., Golod, J., Grybauskus, A., Franc, G., Hammerschmidt, R., Hartman, G., Henn, A., Hershman, D., Hollier, C., Isakeit, T., Isard, S., Jacobson, B., Jardine, D., Kemerait, B., Koenning, S., Malvick, D., Markell, S., Marois, J., Monfort, S., Mueller, D., Mueller, J., Mulrooney, B., Newman, M., Osborne, L., Padgett, G. B., Ruden, B., Rupe, J., Schneider, R., Schwartz, H., Shaner, G., Singh, S., Stromberg, E., Sweets, L., Tenuta, A., Trippett, C., Vaiciunas, S., Yang, X. B., and Zidek, J. 2014. A coordinated effort to manage soybean rust in North America: A success story in soybean disease monitoring. Plant Dis. 98:864-875

Sikora, E. J., Delaney, D. P., Delaney, M. A., Lawrence, K. S., and Pegues, M. 2009. Evaluation of sequential fungicide spray programs for control of soybean rust. Online publication. Plant Health Prog.

Silva, D., Yamanaka, N., Brogin, R., Arias, C., Nepomuceno, A., Di Mauro, A., Pereira, S., Nogueira, L., Passianotto, A., and Abdelnoor, R. 2008. Molecular mapping of two loci that confer resistance to Asian rust in soybean. Theor. Appl. Genet. 117:57-63.

Slaminko, T. L., Miles, M. R., Frederick, R. D., Bonde, M. R., and Hartman, G. L. 2008. New legume hosts of Phakopsora pachyrhizi based on greenhouse evaluations. Plant Dis. 92:767-771.

Slinn, W. G. N. 1982. Predictions for particle deposition to vegetative canopies. Atmos. Environ. 16:1785-1794.

Tan, Y. J., and Sun, Y. L. 1989. Preliminary studies on physiological races of soybean rust. Soybean Sci. China 8:71-74.

Twizeyimana, M., and Hartman, G. L. 2010. Culturing Phakopsora pachyrhizi on detached leaves and urediniospore survival at different temperatures and relative humidities. Plant Dis. 94:1453-1460.

Twizeyimana, M., and Hartman, G. L. 2012. Pathogenic variation of Phakopsora pachyrhizi isolates on soybean in the United States from 2006 to 2009. Plant Dis. 96:75-81.

Twizeyimana, M., Ojiambo, P. S., Sonder, K., Ikotun, T., Hartman, G. L., and Bandyopadhyay, R. 2009. Pathogenic variation of Phakopsora pachyrhizi infecting soybean in Nigeria. Phytopathology 99:353-361.

USDA. 2004. National Strategic Plan for the Integration and Coordination of Soybean Rust Research. https://www.plantmanagementnetwork.org/infocenter/ topic/soybeanrust/symposium/presentations/bennett.pdf 
VanKirk, J. R., Isard, S. A., Cardwell, K. F., and Draper, M. A. 2012. The ipmPIPE: Overviews, Lessons, Opportunities, and Challenges. J. Integr. Pest Manage. 3:C1-C7.

Vittal, R., Haudenshield, J. S., and Hartman, G. L. 2012a. A multiplexed immunofluorescence method identifies Phakopsora pachyrhizi urediniospores and determines their viability. Phytopathology 102:1143-1152.

Vittal, R., Paul, C., Hill, C. B., and Hartman, G. L. 2014. Characterization and quantification of fungal colonization of Phakopsora pachyrhizi in soybean genotypes. Phytopathology 104:86-94.

Vittal, R., Yang, H. C., and Hartman, G. L. 2012b. Anastomosis of germ tubes and migration of nuclei in germ tube networks of the soybean rust pathogen, Phakopsora pachyrhizi. Eur. J. Plant Pathol. 132:163-167.

Walker, D. R., Boerma, H. R., Phillips, D. V., Schneider, R. W., Buckley, J. R., Shipe, E. R., Mueller, J. D., Weaver, D. B., Sikora, E. J., Moore, S. H., Hartman, G. L., Miles, M. R., Harris, D. K., Wright, D. L., Marois, J. J., and Nelson, R. L. 2011. Evaluation of USDA soybean germplasm accessions for resistance to soybean rust in the southern United States. Crop Sci. 51:678-693.

Walker, D. R., Harris, D. K., King, Z. R., Li, Z., Boerma, H. R., Buckley, J. B., Weaver, D. B., Sikora, E. J., Shipe, E. R., Mueller, J. D., Buck, J. W., Schneider, R. W., Marois, J. J., Wright, D. L., and Nelson, R. L. 2014a. Evaluation of soybean germplasm accessions for resistance to Phakopsora pachyrhizi populations in the southeastern United States, 2009-2012. Crop Sci. 54:1673-1689.

Walker, D. R., Harris, D. K., King, Z. R., Li, Z., Phillips, D. V., Buck, J. W., Nelson, R. L., and Boerma, H. R. 2014b. Soybean germplasm accession seedling reactions to soybean rust isolates from Georgia. Crop Sci. 54: 1443-1447.

Ward, N. A., Schneider, R. W., and Robertson, C. L. 2012. Documentation of an extended latent infection period of Phakopsora pachyrhizi, the soybean rust pathogen. Online publication. Plant Health Prog.
Wojciechowski, M. F., Lavin, M., and Sanderson, M. J. 2004. A phylogeny of legumes (Leguminosae) based on analysis of the plastid MATK gene resolves many well-supported subclades within the family. Am. J. Bot. 91: 1846-1862.

Yamanaka, N., Yamaoka, Y., Kato, M., Lemos, L. G., Passianotto, A. L. L., Santos, J. V. M., Benitez, E. R., Abdelnoor, R. V., Soares, R. M., and Suenaga, K. 2010. Development of classification criteria for resistance to soybean rust and differences in virulence among Japanese and Brazilian rust populations. Trop. Plant Pathol. 35:153-162.

Yamaoka, Y., Fujiwars, Y., Kakishima, M., Katsuya, K., and Yamada, K. 2002. Pathogenic races of Phakopsora pachyrhizi on soybean and wild host plants collected in Japan. J. Gen. Plant Pathol. 68:52-56.

Yang, X. B., Li, X., Pan, Z., and Xue, L. 2007. Climate variability and soybean rust forecasts. In: 2nd Natl. SBR Symp. American Phytopathology Society, St. Louis. https://www.plantmanagementnetwork.org/infocenter/topic/ soybeanrust/2007/presentations/Pan.pdf

Yeh, C. C. 1983. Physiological races of Phakopsora pachyrhizi in Taiwan. J. Agric. Res. China 32:69-74.

Yorinori, J. T., Paiva, W. M., Frederick, R. D., Costamilan, L. M., Bertagnolli, P. F., Hartman, G. L., Godoy, C. V., and Nunes, J., Jr. 2005. Epidemics of soybean rust (Phakopsora pachyrhizi) in Brazil and Paraguay from 2001 to 2003. Plant Dis. 89:675-677.

Young, H. M., Liberti, D., Marois, J. J., Wright, D. L., and Harmon, P. 2011a. Identification of candidate resistance genes to Phakopsora pachyrhizi, the causal agent of soybean rust, in the alternative host kudzu, Pueraria spp. (Abstr.) Phytopathology 101:S199.

Young, H. M., Marois, J. J., Wright, D. L., Narváez, D. F., and O’Brien, G. K. 2011 b. Epidemiology of soybean rust in soybean sentinel plots in Florida. Plant Dis. 95:744-750. 